\title{
A last map of yet many firsts: Der Brandberg, 1:200,000
}

\author{
Imre Josef Demhardt ${ }^{\mathrm{a}} *$ \\ ${ }^{a}$ University of Texas at Arlington, demhardt@uta.edu \\ * Corresponding author
}

Keywords: Namibia, Brandberg, Photogrammetry, Reinhard Maack

\begin{abstract}
:
The geographical reconnaissance and subsequent cartographical coverage of southwestern Africa, the coastal hinterland between the mouths of the Kunene $\left(17^{\circ} 15^{\prime} \mathrm{S}\right)$ and Orange Rivers ( $\left.28^{\circ} 37^{\prime} \mathrm{S}\right)$, made slow progress. The Portuguese reached these shores in 1484 but found them a coastal desert. Thus, only in the $19^{\text {th }}$ century European explorers, traders, and missionaries began to visit from the neighbouring Portuguese Angola, but mostly from the British Cape Colony to report on the land and people between the coastal Namib desert and the Kalahari Basin in the heart of the sub-continent.
\end{abstract}

By the end of the pre-colonial era in the 1870s numerous explorative route maps in larger scale had sketched the broad outlines of the complicated scrap land topography of the highlands. They are documented in small-scale overview maps (e.g., Petermann 1878: Originalkarte des Herero \& Kaoko-Landes, 1:2,000,000) and a few mid-scale orientation maps, based on occasion on several reliable astronomical observations (e.g., Theophil Hahn 1879: Original Map of Great Namaqualand and Damaraland, 1:742,016). Throughout the $19^{\text {th }}$ century it was believed that the aloof Omatako twin mountain was the highest peak in southwestern Africa.

In 1884, the whole region was annexed and organized as Protectorate German South West Africa (1884-1915/19). Its administration chronically was short on finance and staffing for systematic surveying and mapping. Thus, the mid- and large-scale map series (1:400,000 to 1:50,000) were restricted on the southern and central highlands, whose white farmlands were the backbone of the colonial economy.

This explains why the Brandberg granite massif, about $26 \times 21 \mathrm{~km}$ and rising to 1,500 above the surrounding gravel plains of the Namib, was shown as a mere grouping of form lines without any spot heights on the official map series until the outbreak of World War I. This void was filled very late by private surveying visits to the remote Brandberg in 1916-18. Reinhard Maack and a small group of helpers with just two ordinary cameras were able to carry out the first extensive terrestrial photogrammetric survey (Fig. 1) in the protectorate.

The map was constructed in 1:100,000 (1918) but published only 1923 in 1:200,000 (1923). It was complemented by trigonometrical observations of spot heights and on January 2, 1918 during the first recorded ascend, a corrected height of Königstein peak by thermobarometer reading to 2,606 m (modern: 2,578). Thus, Königstein was found to be the highest peak in the soon former German protectorate. Simultaneously, this first photogrammetric map of German South West Africa, which story this paper is about, was the last ever surveyed within the collapsing German colonial empire.

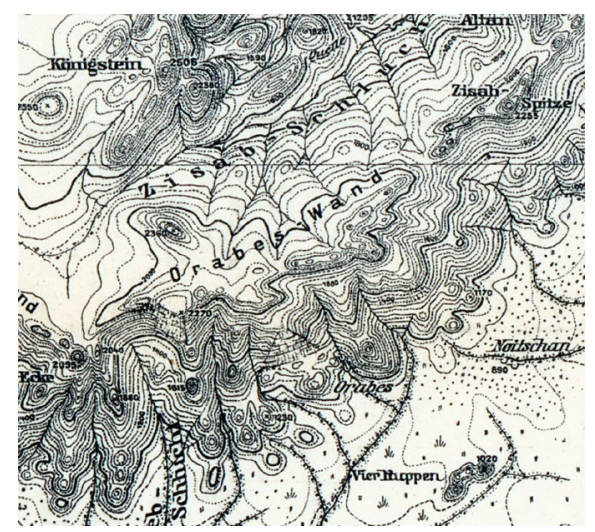

Figure 1. Detail of Der Brandberg, 1:200,000. Densely grouped isohypses in $50 \mathrm{~m}$ intervals on the steep SSE slopes. 